\title{
Hemşirelik Öğrencilerinin Hemşirelik Eğitimi ile İlgili Stres Düzeylerinin Belirlenmesi
}

\author{
Determination of Nursing Students' Stress Levels Related to Nursing Education
}

Zeliha BÜYÜKBAYRAM ${ }^{1}$ [, Derya BIÇAK AYIK ${ }^{1}{ }^{\circledR}$

${ }^{1}$ Siirt Üniversitesi, Sağlık Bilimleri Fakültesi, Hemşirelik Bölümü, Siirt, Türkiye

ÖZ

\begin{abstract}
Amaç: Araştırma, hemşirelik öğrencilerinin hemşirelik eğitimi ile ilgili stres düzeylerini belirlemek amacıyla tanımlayıcı nitelikte yapıld1.

Yöntem: Araştırma evreni, Siirt Üniversitesi Sağlık Yüksekokulu Hemşirelik Bölümü öğrencileri (N=450) oluşturdu. Araştırmanın örneklemini, Aralık 2018- Ocak 2019 tarihleri arasında, araştırma için gönüllü olan 369 öğrenci oluşturdu. Veri toplamada birey tanıtıcı formu ve hemşirelik eğitimi stres ölçeği kullanıldı. Verilerin değerlendirilmesinde frekans, standart sapma, ortalama, anova, kruskal wallis testi, $\mathrm{t}$ testi, mann-whitney u testi ve pearson korelasyon analizi kullanıldı. Tüm bulgular $\mathrm{p}<0.05$ anlamlılık düzeyinde alınmıştır.

Bulgular: Araştırma kapsamına alınan hemşirelik öğrencilerin \%50.7'sini kız öğrencilerin oluşturduğu ve tüm öğrencilerin yaş ortalamalarının $21.60 \pm 2.34$ olduğu, not ortalamalarının $73.11 \pm 7.22$ olduğu, \%40.4'ünün III. sınıfta öğrenim gördüğü, \%69.4'ünün aile gelir durumunun orta düzeyde olduğu, \%41.7'sinin yurtta yaşadığı, \%63.7'sinin hemşirelik bölümünü isteyerek seçtiği, \%47.2'sinin mezun olduktan sonra hemşirelik mesleğini yapmak istediği ve \%34.4'ünün uygulamaya çıktıklarında merak duygusu yaşadığı saptandı. Hemşirelik eğitimi stres ölçeği toplam puan ortalaması $57.75 \pm 16.52$, akademik stres alt boyutu $28.72 \pm 8.67$ ve uygulama stres alt boyut puan ortalamasının $29.02 \pm 8.70$ olduğu saptandi. Cinsiyet ile stres düzeyi arasında anlamlı fark olduğu saptandı. Ayrıca staj uygulamasına yönelik kaygı, stres ve korku hissi ile stres düzeyi arasında da anlamlı fark olduğu saptandı.

Sonuç: Araştırmada hemşirelik öğrencilerinin eğitimde yaşadıkları stresin orta düzeyde olduğu ve stres düzeyi ile derslerin not ortalaması arasında pozitif yönde anlamlı bir ilişki olduğu bulundu.
\end{abstract}

Anahtar Kelimeler: Hemşirelik eğitimi, Hemşirelik öğrencileri, Stres.

ABSTRACT

Objective: The research was carried out as a descriptive study in order to determine the stress levels of nursing students related to nursing education.

Methods: The population of the research consisted of the students of the Nursing Department of the School of Health in Siirt University ( $\mathrm{N}=450)$. The sample of the research consisted of 369 students who accepted to join in the study between December 2018 and January 2019. In data collecting; student identification form, and Nursing Education Stress Scale were used. Frequency, standard deviation, mean, kruskal wallis test, anova, $t$ test and pearson correlation analysis were used to evaluate the data. All findings were tested at a level of $\mathrm{p}<0.05$.

Results: Of the nursing students included in the study, 50.7\% were female and the average age of all students was $21.60 \pm 2.34$, their grade point average was $73.11 \pm 7.22,40.4 \%$ was in grade 3 , and $69.4 \%$ of them family income status were in middle level, It was determined that $41.7 \%$ of them lived in dormitories, $63.7 \%$ of them preferred nursing department willingly, $47.2 \%$ of them wanted to work as a nurse after graduation and $34.4 \%$ of them experienced a sense of curiosity when they came into practice. The mean total score of the Nursing Education Stress Scale was $57.75 \pm 16.52$, the academic stress sub-dimension was $28.72 \pm 8.67$ and the application stress sub-dimension score was $29.02 \pm 8.70$.

Conclusion: In the research, it was found that the mean score of nursing students' Nursing Education Stress Scale was moderate. It was obtained that there was a positive correlation between total and all sub-dimension scores of the Nursing Education Stress Scale and the grade point average.

Sorumlu Yazar: Zeliha BÜYÜKBAYRAM

Siirt Üniversitesi, Sağlık Bilimler Fakültesi, Hemşirelik Bölümü, Siirt, Türkiye

zeliha_bbayram@hotmail.com

Geliş Tarihi: 08.05.2019 - Kabul Tarihi: 09.02.2020 
Key words: Nursing education, Nursing students, Stress.

\section{GİRiş}

Hemşirelik eğitimi teori ve uygulamayı içeren, gözlem, teorik bilgi ve yoruma gereksinim duyulan bir süreçtir. Bu süreçte hemşirelik öğrencilerinin sağlıklı iletiş̧im kurabilen, özsayg1 ve özgüven seviyeleri yüksek bireyler olarak yetişmeleri mesleki başarı açısından oldukça önemlidir $(1,2)$. Ancak hemşirelik öğrencileri, eğitim süreçleri boyunca çeşitli stresörlere maruz kalmaktadırlar. Bu stresörler; akademik (sınavlar ve değerlendirmeler, eğitimdeki başarısızlık korkusu, iş yükü ile ilgili sorunlar, vb.), klinik stresörler (iş, hata yapma korkusu, hastaların ölümüne veya acılarına olumsuz tepkiler, meslek grubunun diğer üyeleriyle ilişkiler vb.) ve kişisel / sosyal stresörlerdir $(3,4)$. Literatüre baktığımızda hemşirelik öğrencileri farklı alanlarda eğitim gören öğrencilere göre daha yüksek düzeyde stres yaşadıkları ve hemşirelik öğrencilerin eğitim süreçleri boyunca daha çok akademik ve klinik alanda stres yaşadıkları görülmüş̧ür (4-6). Özellikle klinik uygulama alanları, öğrenciler için profesyonel bilgi ve beceri gelişimi açısından oldukça önemli olmasına rağmen, aynı zamanda önemli bir stres nedenidir $(6,7)$. Hemşirelik öğrencileri klinik uygulamada alışılmadık ortamlara maruz kaldıkları için hem mesleki strese hem de kişisel strese maruz kalmaktadırlar (8). Martos ve ark. klinik uygulamanın, hemşirelik öğrencileri için programın diğer yönleriyle karşılaş̧ırıldığında en yüksek düzeyde stres ürettiğini öne sürmektedir (3). Bu da, hemşirelik öğrencilerinin diğer disiplinlerdeki öğrencilere göre daha yüksek düzeyde stres yaşadığını göstermektedir $(9,10)$.

Stres, hemşirelik öğrencilerinin akademik performansını ve refahını etkileyen psikolojik bir faktördür (3). Bu durum, gelecekteki hemşirelerin eğitiminde stres düzeylerini ve kaynaklarını belirlemeyi amaçlayan geniş bir araştırma grubunun geliştirilmesine yol açmıştır $(8,9,11)$.

Literatür incelendiğinde stresin öğrencilerin klinik beceri ve performansını etkilediği görülmektedir ancak hemşirelik öğrencilerin hemşirelik eğitimi ile ilgili yaşadıkları stresi araştıran çalışmaların nadir olduğu tespit edilmiştir $(3,8,9,12)$. Bilgiler doğrultusunda, bu çalışma ile siirt üniversitesi sağllk yüksek okulu hemşirelik bölümü öğrencilerinin eğitimleri esnasında yaşadıkları stresinin belirlenmesi amaçlanmıştır.

\section{GEREÇ VE YÖNTEMLER}

\section{Araştırmanın Tipi}

Araştırma, hemşirelik bölümü öğrencilerinin hemşirelik eğitimi ile ilgili stres düzeylerinin belirlenmesi amacıyla tanımlayıcı nitelikte yapıldı.

\section{Araştırmanın Yeri ve Zamanı}

Araştırma, Siirt Üniversitesi Sağlık Yüksekokulu Hemşirelik Bölümü öğrencilerine yönelik Aralık 2018-Ocak 2019 tarihleri arasında yapıldı. Bu yüksekokuldaki 2, 3 ve 4. Sınıftaki ögrenciler haftalık 6 saat temel torik ders almakta olup 8 saat klinik uygulamaya çıkmaktadır. Birinci sınıf öğrencileri ise ilk dönem klinik uygulamaya çıkmayıp haftalık 4 saat 
laboratuvar uygulaması almaktadır. Yüksekokulun akademik kadrosu 3 araştırma görevlisi ve 12 öğretim elamanından oluşmaktadır.

\section{Araştırmanın Evren ve Örneklemi}

Araştırma evrenini, Siirt Üniversitesi Sağlık Yüksekokulu Hemşirelik Bölümü 2. 3. 4. sınıf öğrencilerinin tamamı $(\mathrm{N}=450)$ oluşturdu. Veri toplama tarihlerinde 1. sınıf öğrencileri klinik uygulama deneyimi olmadığından çalışmaya dahil edilmedi. Örneklemeye gidilmeden araştırma için gönüllü olan öğrenciler çalışmaya dahil edildi. Araştırma; veri toplama aşamasında devamsızlık yapan ve çalışma için gönüllü olmayan öğrencilerin $(n=81)$ olması nedeniyle 369 öğrenci ile tamamlanmıştır.

\section{Veri toplama araçları;}

Birey Tanıtıcı Formu; Araştırmaya katılan hemşirelik öğrencilerin demografik verilerini ve hemşirelik eğitimlerine ilişkin bazı bilgileri içeren, araştırmacı tarafından hazırlanan 9 sorudan (yaş, cinsiyet, eğitim durumu, aile gelir durumu, nerede yaşadığı, mesleği tercih etme istediği, çalışmak istediği alan, klinik uygulamada yaşadığı duygu durumu ve akademik başarı ortalaması) oluşmaktadır $(4,12,13)$.

Hemşirelik Eğitimi Stres Ölçeği (HESÖ); Hemşirelik eğitimi stres ölçeği Rhead tarafından 1995 yılında geliştirilmiştir. Ölçeğin Türkçe geçerlilik güveniliği Karaca ve arkadaşları (2014) tarafından yapılmıştır (14). Ölçek 32 maddeden oluşmaktadır. $4^{\text {ee }}$ ü Likert tipinde olup 0-3 puan arasında (" 0 " hiç stres verici değil, " 3 ” çok stres verici) hesaplanmaktadır. Ölçek, uygulama stresi alt boyutu ve akademik stres alt boyutundan oluşmaktadır. Akademik stres alt boyutu; 1,2,3,6,8,10,12,14,17,20,22,23,26,28,30,31 maddeler, Uygulama stres alt boyutu; 4,5,7,9,11,13,15,16,18,19,21,24,25,27,29,32 maddelerinden oluşmaktadır. Alt boyutlarının her birinden alınabilecek en az puan 0 iken maksimum puan 48'dır. Ölçekten alınabilecek puan 0-96 arasındadır. Ölçekten alınan puanın artması stres düzeyinin yükseldiğini göstermektedir. Ölçeğin Cronbach alpha güvenirlik katsayılarının 0.81-0.93 arasında bulunmuştur $(7,14,15)$. Çalışmamızda ise toplam güvenirlik katsayısı cronbach alpha değeri; 0.91, alt boyutlarının güvenirlik katsayıları akademik stres alt boyutu için 0.86 , uygulama stresi alt boyutu için ise 0.83 olarak bulundu.

\section{Verilerinin Değerlendirilmesi}

Verilerin analizi için SPSS 20.0 (Statistical Pack age for Social Science) istatistik paket programı kullanıldı. Tanımlayıcı istatistikler birim sayısı (n), yüzde (\%), ortalama \pm standart sapma ( $\mathrm{x} \pm$ ss), ortanca (M), 25.yüzdelik (Ç1), 75.yüzdelik (Ç3) değerleri olarak verildi. Sayısal değişkenlere ait verilerin normal dağılımı Q-Q grafikleri ve Shapiro Wilk normallik testi ile değerlendirildi. Normal dağılım gösteren değişkenlerde iki grup karşılaştırmaları bağımsız iki örnek t testi, normal dağılım göstermeyen değişkenlerde Mann-Whitney U testi ile yapıldı. İkiden daha fazla grup karşılaştırmaları normal dağılım gösteren değişkenlerde Tek Yönlü Varyans Analizi, normal dağılım göstermeyen değişkenlerde Kruskal-Wallis analizi ile değerlendirildi. $\mathrm{p}<0.05$ değeri istatistiksel olarak önemli kabul edildi. 


\section{Araştırmanın Etik Yönü}

Araştırma öncesi, Siirt Üniversitesi Girişimsel Olmayan Klinik Araştırmalar Etik Kurulu'ndan etik onay (03.12.2018/E.16339), Siirt Üniversitesi Sağlık Yüksekokulu Müdürlügü’nden (02.11.2018/E.15214) gerekli izin ve araştırma için gönüllü olan öğrencilerden sözlü ve yazılı onam alındı.

\section{BULGULAR}

Araştırma kapsamına alınan hemşirelik öğrencilerinin \%50.7'sini kız öğrencilerin oluşturduğu ve tüm öğrencilerin yaş ortalamalarının $21.60 \pm 2.34$ olduğu, not ortalamalarının 73.11 7.22 olduğu saptand1. Öğrencilerin \%40.4'ünün III. sinıfta öğrenim gördüğü, \%69.4'ünün aile gelir durumunun orta düzeyde olduğu, \%41.7'sinin yurtta yaşadığı, \%63.7'sinin hemşirelik bölümünü isteyerek tercih ettiği, \%47.2'sinin mezun olduğu zaman hemşire olarak çalışmak istediği ve \%72.6'ünün uygulamaya çıktıklarında merak duygusu yaşadıkları saptandı (Tablo 1).

Tablo 1. Öğrencilerin Tanıtıcı Özelliklerine Göre Dağılımı (n=369)

\begin{tabular}{lcc}
\hline Tanıtıcı Özellikler & S & $\%$ \\
\hline Cinsiyet & 187 & 50.7 \\
Kadın & 182 & 49.3 \\
Erkek & 124 & 33.6 \\
\hline Eğitim Gördü̆ğ Sınıf & 149 & 40.4 \\
2. Sınıf & 96 & \\
3. Sınıf & & 17.6 \\
4. Sınıf & 65 & 69.4 \\
\hline Aile Gelir Durumu & 256 & 13.0 \\
Iyi & 48 & \\
Orta & & 41.7 \\
Kötü & 154 & 26.0 \\
\hline Yaşadı̆̆ı Yer & 96 & 2.7 \\
Yurtta & 10 & 29.6 \\
Evde aileyle & 109 & \\
Evde yalnız & & 63.7 \\
Evde Arkadaşlarla & 235 & 36.3 \\
\hline Hemşirelik Mesleğini isteyerek mi tercih ettiniz? & 134 & \\
Evet & & 6.0 \\
Hayır & & 47.1 \\
\hline Mezuniyet Sonrası Çalışmak İstediğiniz Alan & 22 & 33.6 \\
Öğretmen & 174 & 13.3 \\
Hemşire & 124 & \\
Akademisyen & 49 & \\
Kararsız & & 48.2 \\
\hline Uygulamaya Çıktığında Hissettiği Duygular & & 51.8 \\
Heyecan & 178 & 72.6 \\
Var & 191 & 27.4 \\
Yok & & \\
Merak & 268 & \\
Var & 101 & \\
Yok & 105 & \\
Kaygı & 264 & \\
Var & & \\
Yok & & \\
\hline
\end{tabular}


Tablo 1. Öğrencilerin Tanıtıcı Özelliklerine Göre Dağılımı (n=369) (devam)

\begin{tabular}{lcc}
\hline Tanıtıcı Özellikler & S & \% \\
\hline Uygulamaya Çıktığında Hissettiği Duygular & & \\
Stres & & 32.8 \\
Var & 121 & 67.2 \\
Yok & 248 & 16.5 \\
Korku & 61 & 83.5 \\
Var & 308 & 12.2 \\
Yok & & 87.8 \\
Hiçbiri & 45 & \\
Var & 324 & \\
Yok & $\mathbf{7 3 . 1 1} \pm \mathbf{7 . 2 2}$ & \\
\hline Not Ortalaması & $\mathbf{2 1 . 6 0 \pm \mathbf { 2 . 3 4 }}$ \\
\hline Yaş Ortalaması & & \\
\hline
\end{tabular}

HESÖ toplam puan ortalamas1 $57.75 \pm 16.52$, akademik stres alt boyutu $28.72 \pm 8.67$ ve uygulama stres alt boyut puan ortalamasının 29.02 \pm 8.70 olarak saptandı (Tablo 2).

Tablo 2. Hemşirelik Eğitimi Stres Ölçeği Puan Ortalamaları (n=369)

\begin{tabular}{lcccc}
\hline $\begin{array}{l}\text { HESÖ ve } \\
\text { Alt Boyutları }\end{array}$ & $\begin{array}{c}\text { Madde } \\
\text { sayısı }\end{array}$ & $\begin{array}{c}\text { Min. } \\
\text { Puan }\end{array}$ & $\begin{array}{c}\text { Max. } \\
\text { Puan }\end{array}$ & $\overline{\mathbf{X}} \pm \mathbf{S S}$ \\
\hline Akademik stresi altboyutu & 16 & 0 & 48 & $28.72 \pm 8.67$ \\
Uygulama stres alt boyutu & 16 & 0 & 48 & $29.02 \pm 8.70$ \\
Toplam HESÖ & 32 & 0 & 96 & $57.75 \pm 16.52$ \\
\hline
\end{tabular}

Araştırmaya dahil edilen öğrencilerin demografik özelliklerine göre hemşirelik eğitimi stres ölçek puan karşılaştırılması Tablo 3 'te gösterilmiştir. Çalışmada kız öğrencilerin HESÖ ve tüm alt boyut puan ortalamaları erkeklere göre yüksek olup aradaki fark istatistiksel olarak anlamlı bulundu $(\mathrm{p}<0.05)$. Dördüncü sınıf öğrencilerinin HESÖ ve tüm alt boyut puan ortalamaları, 2. ve 3. sınıf öğrencilerine göre daha yüksek ancak istatistiksel olarak anlamlı bir fark bulunmadı ( $p>0.05$ ). Aile gelir düzeyi orta seviyede olan öğrencilerin HESÖ ve tüm alt boyut puan ortalamaları, diğer seviyelerdeki öğrencilere göre yüksek olduğu ancak istatistiksel olarak anlamlı bir fark olmadığı tespit edildi ( $>>0.05$ ). Yurtta yaşayan öğrencilerin HESÖ ve tüm alt boyut puan ortalamaları, diğerlerine göre daha yüksek olduğu ancak istatistiksel olarak anlamlı bir fark olmadığı tespit edildi ( $\mathrm{p}>0.05)$. “Bölümünüzü isteyerek mi seçtiniz?' sorusuna 'evet' diyenlerin HESÖ puan ortalaması hayır diyenlere göre daha yüksek olduğu ancak istatistiksel olarak anlamlı bir fark bulunmadığı tespit edildi ( $p>0.05)$. Mezun olduktan sonra akademisyen olarak çalışmak isteyenlerin puan ortalamaları diğerlerine göre yüksek olup aradaki fark istatistiksel olarak anlamsız bulundu ( $>0.05$ ). Öğrencilerin uygulamaya yönelik HESÖ ile kayg1, stres ve korku hislerindeki fark istatistiksel olarak anlamlı bulundu $(\mathrm{p}<0.05)$ (Tablo 3).

Araştırma alınan öğrencilerin, HESÖ ve alt boyutları puanı ile derslerinin not ortalaması arasında pozitif yönde anlamlı bir ilişki olduğu saptandı $(\mathrm{p}<0.05)$ (Tablo 4). 
Adnan Menderes Üniversitesi Sağlık Bilimleri Fakültesi Dergisi 2020: 4(2); $90-99$

Journal of Adnan Menderes University Health Sciences Faculty

Tablo 3. Öğrencilerin Demografik Özelliklerine Göre Hemşirelik Eğitimi Stres Ölçeği Puan Ortalamalarının Karşılaştırılması $(\mathrm{n}=369)$

\begin{tabular}{|c|c|c|c|}
\hline Tanıtıcı Özellikler & $\begin{array}{l}\text { Akademik Stres } \\
\text { Alt Boyutu } \\
\bar{x} \pm s s\end{array}$ & $\begin{array}{l}\text { Uygulama Stres } \\
\text { Alt Boyutu } \\
\bar{x} \pm s s\end{array}$ & $\begin{array}{l}\text { HESÖ } \\
\bar{x} \pm s s\end{array}$ \\
\hline \multicolumn{4}{|l|}{ Cinsiyet } \\
\hline Kadin & $29.78 \pm 8.08$ & $30.87 \pm 7.97$ & $60.65 \pm 15.15$ \\
\hline Erkek & $27.64 \pm 9.14$ & $27.13 \pm 9.03$ & $54.78 \pm 17.36$ \\
\hline İstatistiksel analiz* & $t=2.378 ; p=\mathbf{0 . 0 1 4}$ & $t=4.215 ; p<\mathbf{0 . 0 0 1}$ & $t=3.468 ; p=\mathbf{0 . 0 1 4}$ \\
\hline \multicolumn{4}{|l|}{ Eğitim Gördüğü Sınıf } \\
\hline 2. Sinif & $28.93 \pm 8.61$ & $28.50 \pm 8.51$ & $57.44 \pm 16.19$ \\
\hline 3. Sinıf & $28.37 \pm 9.02$ & $28.81 \pm 8.98$ & $57.18 \pm 17.27$ \\
\hline 4. Sinif & $29.01 \pm 8.28$ & $30.04 \pm 8.51$ & $59.05 \pm 15.83$ \\
\hline İstatistiksel analiz $* *$ & $F=0.201 ; p=0.814$ & $F=0.919 ; p=0.402$ & $F=0.401 ; p=0.666$ \\
\hline \multicolumn{4}{|l|}{ Aile Gelir Durumu } \\
\hline İyi & $28.78 \pm 10.21$ & $28.89 \pm 10.36$ & $57.67 \pm 19.95$ \\
\hline Orta & $28.68 \pm 8.04$ & $29.16 \pm 7.91$ & $57.84 \pm 15.07$ \\
\hline Kötü & $28.89 \pm 9.82$ & $28.52 \pm 10.32$ & $57.41 \pm 19.06$ \\
\hline İstatistiksel analiz $* *$ & $F=0.142 ; p=0.988$ & $F=0.114 ; p=0.881$ & $F=0.145 ; p=0.982$ \\
\hline Evet & $28.59 \pm 8.40$ & $29.25 \pm 8.43$ & $57.84 \pm 15.86$ \\
\hline Hayır & $28.96 \pm 9.16$ & $28.64 \pm 9.18$ & $57.60 \pm 17.67$ \\
\hline \multirow[t]{2}{*}{ İstatistiksel analiz * } & $t=0.392 ; p=0.691$ & $t=0.644 ; p=0.511$ & $t=0.133 ; p=0.892$ \\
\hline & $M\left(C_{1}-C_{3}\right)$ & $M\left(C_{1}-C_{3}\right)$ & $M\left(C_{1}-C_{3}\right)$ \\
\hline \multicolumn{4}{|l|}{ Yaşadığı Yer } \\
\hline Yurtta & $30.50(24.00-35.00)$ & $30.00(24.00-36.00)$ & $61.00(49.75-70.00)$ \\
\hline Evde aileyle & $28.00(23.00-34.00)$ & $28.00(23.00-34.00)$ & $56.50(47.00-68.00)$ \\
\hline Evde yalnız & $27.50(13.00-34.75)$ & $25.50(16.75-34.25)$ & $50.50(29.75-69.00)$ \\
\hline Evde Arkadaşlarla & $29.00(22.50-34.50)$ & $29.00(22.00-34.50)$ & $58.00(45.50-69.00)$ \\
\hline İstatistiksel analiz $* * *$ & $K W_{\mathrm{x}}^{2}=3.501 ; p=0.324$ & $K W_{\mathrm{x}}^{2}=4.763 ; p=0.191$ & $K W_{\mathrm{x}}^{2}=4.012 ; p=0.914$ \\
\hline \multicolumn{4}{|c|}{$\begin{array}{l}\text { Mezuniyet Sonrası Çalışmak } \\
\text { İstediğiniz Alan }\end{array}$} \\
\hline Öğretmen & $27.50(21.25-34.00)$ & $25.00(18.50-34.00)$ & $52.50(42.25-70.25)$ \\
\hline Hemşire & $29.00(24.00-34.00)$ & $29.50(24.00-35.00)$ & $58.00(48.00-68.00)$ \\
\hline Akademisyen & $31.00(24.00-36.00)$ & $30.00(24.00-35.00)$ & $62.00(49.00-70.00)$ \\
\hline Kararsiz & $28.00(21.00-35.00)$ & $28.00(21.50-35.50)$ & $54.00(40.50-70.00)$ \\
\hline İstatistiksel analiz $* * *$ & $K W_{\mathrm{x}}^{2}=3.000 \quad p=0.391$ & $K W_{\mathrm{x}}^{2}:=0.294 \quad p=0.344$ & $K W_{\mathrm{x}}^{2}=2.952 ; p=0.390$ \\
\hline \multicolumn{4}{|l|}{ Uygulamaya Çıktığında } \\
\hline \multicolumn{4}{|l|}{ Hissettiği Duygular } \\
\hline \multicolumn{4}{|l|}{ Heyecan } \\
\hline Var & $29.00(23.00-34.00)$ & $28.00(22.75-34.00)$ & $57.00(47.00-68.00)$ \\
\hline Yok & $30.00(24.00-35.00)$ & $30.00(24.00-36.00)$ & $61.00(49.00-70.00)$ \\
\hline İstatistiksel analiz $* * * *$ & $z=1.137 ; p=0.256$ & $z=1.538 ; p=0.124$ & $z=1.422 ; p=0.155$ \\
\hline \multicolumn{4}{|l|}{ Merak } \\
\hline Var & $29.00(24.00-35.00)$ & $29.00(23.00-35.00)$ & $58.00(47.00-70.00)$ \\
\hline Yok & $29.00(24.00-34.00)$ & $29.00(22.50-35.50)$ & $59.00(49.00-68.00)$ \\
\hline İstatistiksel analiz $* * * *$ & $z=0.443 ; p=0.658$ & $z=0.517 ; p=0.605$ & $z=0.503 ; p=0.615$ \\
\hline \multicolumn{4}{|l|}{ Kaygl } \\
\hline Var & $32.00(25.00-35.00)$ & $32.00(25.00-36.00)$ & $65.00(50.50-70.00)$ \\
\hline Yok & $29.00(23.00-34.00)$ & $28.00(23.00-34.00)$ & $56.00(47.00-69.00)$ \\
\hline İstatistiksel analiz $* * * *$ & $z=1.991 ; p=\mathbf{0 . 0 4 6}$ & $z=2.275 ; p=\mathbf{0 . 0 2 3}$ & $z=2.361 ; p=\mathbf{0 . 0 1 8}$ \\
\hline \multicolumn{4}{|l|}{ Stres } \\
\hline Var & $33.00(27.00-36.00)$ & $34.00(27.00-37.00)$ & $66.00(54.50-72.50)$ \\
\hline Yok & $28.00(22.00-33.00)$ & $27.50(22.00-34.00)$ & $54.50(45.00-66.00)$ \\
\hline İstatistiksel analiz $* * * *$ & $z=4.570 ; p<\mathbf{0 . 0 0 1}$ & $z=5.308 ; p<\mathbf{0 . 0 0 1}$ & $z=5.348 ; p<\mathbf{0 . 0 0 1}$ \\
\hline \multicolumn{4}{|l|}{ Korku } \\
\hline Var & $33.00(27.50-36.00)$ & $34.00(27.50-39.00)$ & $68.00(53.00-72.50)$ \\
\hline Yok & $29.00(23.00-34.00)$ & $28.00(23.00-34.00)$ & $57.00(47.00-68.00)$ \\
\hline İstatistiksel analiz $* * * *$ & $z=2.568 ; p=\mathbf{0 . 0 1 0}$ & $z=3.931 ; p<\mathbf{0 . 0 0 1}$ & $z=3.500 ; p<\mathbf{0 . 0 0 1}$ \\
\hline \multicolumn{4}{|l|}{ Hiçbiri } \\
\hline Var & $29.00(21.50-34.50)$ & $29.00(19.00-36.00)$ & $59.00(41.50-69.00)$ \\
\hline Yok & $30.00(24.00-34.00)$ & $29.00(23.00-35.00)$ & $58.00(47.25-69.00)$ \\
\hline İstatistiksel analiz $* * * *$ & $z=0.519 ; p=0.604$ & $z=0.674 ; p=0.500$ & $z=0.651 ; p=0.515$ \\
\hline
\end{tabular}


Tablo 4. Hemşirelik Eğitimi Stres Ölçeği ve Derslerin Not Ortalaması Arasındaki Korelasyon İlişkisi

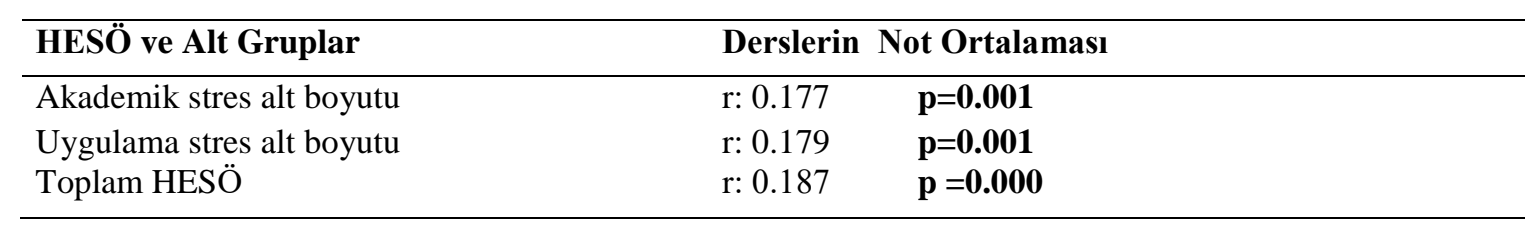

\section{TARTIŞMA}

Hemşirelik öğrencilerinin hemşirelik eğitimi ile ilgili stres düzeylerinin belirlenmesi amacıyla yapılan çalışmada; HESÖ toplam puan, akademik stres alt boyutu ve uygulama stres alt boyut puan ortalamaları, ortalamanın üstünde olduğu saptandı. Buna göre öğrencilerin hemşirelik eğitimleri ile ilgili ortalamanın üstünde stres yaşadığı söylenebilir. Literatür incelendiğinde konu ile ilgili araştırmalarda; Ağaçdiken ve arkadaşlarının (2016) yaptıkları çalışmada öğrencilerin HESÖ'den aldıkları toplam puan, akademik stres alt boyut ve uygulama alt boyut puan ortalamaları çalışmamız ile benzer olduğu saptanmıştır (15). Güler ve arkadaşının (2010) yaptıkları çalışma da benzer şekilde öğrencilerin \%65.8'inin eğitim ile ilgili; bu öğrencilerin \%25.8'inin derslerle, \%10'unun ise uygulama alanı ile ilgili stres yaşadığ saptanmıştır (16). Ergin ve arkadaşlarının (2018) yaptıkları benzer bir çalışmada, öğrencilerin HESÖ toplam ve alt boyutlarının puan ortalamaları, ortalamanın üstünde olduğu saptanmıştır (7). Çalışmamızdan farklı olarak Karagözoğlu ve arkadaşlarının (2014) yaptığı çalışmada hemşirelik öğrencilerinin stres puan ortalaması, ortalamanın altında olduğu belirlenmiştir. Bu sonuç, çalışmamızı desteklememektedir (17). Bu çalışma sonucundaki farklılığının öğrencilerin yaşadığı farklı klinik deneyimlerinden kaynaklı olduğu söylenebilir.

Çalışmamızda kız öğrencilerin HESÖ puan toplamı ve tüm alt boyutları puan ortalamaları erkeklere göre daha yüksek olduğu aradaki fark istatistiksel olarak anlamlı olduğu saptandı. Çalışmamıza benzer Ergin ve arkadaşlarının (2018) yaptıkları çalışmada, cinsiyet göre HESÖ toplam puanı ile tüm alt boyutları arasında istatistiksel açıdan önemli bir fark olduğu saptanmıştır (7). Yapılan diğer çalışmalarda da çalışmamıza benzer sonuçlar elde edilmiştir $(18,19)$. Çalışmamızın aksine yapılan diğer çalışmalarda ise cinsiyetin klinik strese etkili olmadığı tespit edilmiştir (17,20). Bu farkın nedeni erkeklerin kızlardan farklı olarak streslerini daha basit ve az ifade etmelerinden kaynaklandığı düşünülebilir. Dördüncü sınıf öğrencilerinin HESÖ toplam ve tüm alt boyutları puan ortalamaları, 2. ve 3. sınıf öğrencilerine göre yüksek olup aradaki fark istatistiksel olarak anlamsız olduğu saptandı. Çalışmamız, Ergin ve arkadaşlarının (2018) yapmış oldukları çalışma sonuçlarıyla benzerlik göstermektedir (7). Çalışmamızın aksine Singh ve arkadaşlarının (2013) yapmış olduğu çalışmada uygulama stresinin 2. sınıf öğrencilerinde daha yüksek bulunmuştur (19). Hemşirelik eğitiminde her y1l farklı alan uygulamalarının olması ve teorik bilgi yoğunluğu ile stresin devam ettiği düşünülebilir. Ayrıca 4. sınıf öğrencilerinde stres düzeyin yüksek çıkmasının nedenin mezun olduktan sonra atanamama düşüncesinden kaynaklanabilir. Öğrencilerin aile geliri orta düzeyi HESÖ toplam ve tüm alt boyutları puan ortalamaları, kötü ve iyiye göre yüksek olduğu aradaki fark istatistiksel olarak anlamsız olduğu saptandı. Çalışmamıza benzer olarak Çakmak ve arkadaşının (2005) yapmış olduğu araştırmada öğrencilerin kaygı düzeyleri ile ailelerinin ekonomik durumları arasında istatistiksel açıdan anlamlı fark saptanmamıştır (21). Öğrencilerin stres kaynağının nedeni genellikle ders ve eğitimcilerle ilgili etmenler olabilmektedir. Gelir 
durumu fark etmeksizin aynı ortamda eğitim gören bütün öğrenciler aynı etmenlerle karşılaşmaktadırlar. $\mathrm{Bu}$ nedenden dolayı gelir durumunun stres üzerinde etkili olmadığ söylenebilir. Öğrencilerin yaşadığı yer olarak yurt HESÖ puan toplamı ve tüm alt boyutları puan ortalamaları, diğerlerine göre daha yüksek olup aradaki fark istatistiksel olarak anlamsız olduğu saptandı. Yurtta yaşayan öğrencilerin aile ortamından uzakta olmaları, yetersiz olan ortam ve imkanları diğer öğrencilerle paylaşmak zorunda kalmaları, arkadaşlarıyla yaşadığı sorunlar ya da yurt koşullarının öğrencide bıraktığı olumsuz etki öğrencilerin daha fazla stres yaşamasına yol açtığı söylenebilir. "Bölümünüzü isteyerek mi seçtiniz?' sorusuna 'evet' diyenlerin HESÖ toplam puan ortalamaları yüksek olup aradaki fark istatistiksel olarak anlamsız olduğu saptandı. Öğrencilerin çoğu mesleğini isteyerek seçmesi iş olanaklarının daha fazla olmasından kaynaklı olduğu söylenebilir fakat değişen sağlık politikaları ile birlikte işe girmenin zorlaşması sonucu öğrencilerde stres düzeyinin arttığı söylenebilir. Mezun olduktan sonra akademisyen olarak çalışmak isteyenlerin puan ortalamaları diğerlerine göre daha yüksek olduğu aradaki fark istatistiksel olarak anlamsız olduğu saptandı. Akademisyen olarak çalışmak isteyenlerin stres düzeyinin daha yüksek olmasının nedeni kliniklerdeki nöbetli çalışma sistemi ve iş yükünü kaldıramama düşüncesinden kaynaklanabilir. Araştırma kapsamına alınan öğrencilerin, toplam HESÖ puan ve alt boyutları ile derslerinin not ortalaması arasında pozitif yönde bir ilişki olduğu saptanmıştır. Çalışmamızda öğrencilerin orta düzeyde stres yaşamaları ders başarısını olumlu etkilediği söylenebilir.

\section{SONUÇ}

Sonuç olarak, hemşirelik öğrencilerinin orta düzeyde stres yaşadıkları görülmüştür. Ayrıca stres düzeyi ile öğrencilerin akademik not ortalaması arasında anlamlı bir ilişki olduğu tespit edilmiştir. Orta düzeyde yaşanan bu stresin öğrencilerde güdülemeyi arttırdığ 1 ve bu durumunda akademik başarıyı olumlu yönde etkilediği söylenebilir. Öğrencilerin uygulamaya çıktıklarında kaygı, stres ve korku gibi duyguları hissetmeleri hazırlıksız bir şekilde yeni bir ortama girmelerinden kaynaklandığı düşünülmektedir.

$\mathrm{Bu}$ doğrultuda, klinik uygulama öncesi hemşire ve öğretim elemanlarının öğrencilere yönelik klinik sahayı kapsayan oryantasyon programları düzenlenmesi önerilebilir. Ayrıca okul ortamındaki mevcut laboratuvar koşullarının düzeltilmesi ve simülasyon uygulamalarına yer verilmesi ile öğrencilerin uygulamaya yönelik kaygı stres ve korkularının azalacağı düşünülmektedir.

\section{Araştırmanın Etik Yönü}

Araştırma öncesi, Siirt Üniversitesi Girişimsel Olmayan Klinik Araştırmalar Etik Kurulu'ndan etik onay (03.12.2018/E.16339), Siirt Üniversitesi Sağlık Yüksekokulu Müdürlügü̈nden (02.11.2018/E.15214) gerekli izin ve araştırma için gönüllü olan öğrencilerden sözlü ve yazılı onam alındı.

\section{KAYNAKLAR}

1. Dinçer, F., \& Öztunç, G. (2009). Hemşirelik ve ebelik öğrencilerinin benlik saygısı ve atılganlık düzeyleri. Hacettepe Üniversitesi Hemşirelik Fakültesi Dergisi, 16(2), 22-33. 
2. Tüfekci, F. G., \& Yıldız, A. (2009). Öğrencilerin hemşireliği tercih etme gerekçeleri ve gelecekleri ile ilgili görüşleri. Anadolu Hemşirelik ve Sağllk Bilimleri Dergisi, 12(1), 31-37.

3. Pulido-Martos, M., Augusto-Landa, J. M., \& Lopez-Zafra, E. (2012). Sources of stress in nursing students: A systematic review of quantitative studies. International Nursing Review, 59(1), 15-25. https://doi.org/10.1111/j.1466-7657.2011.00939.x

4. Reeve, K. L., Shumaker, C. J., Yearwood, E. L., Crowell, N. A., \& Riley, J. B. (2013). Perceived stress and social support in undergraduate nursing students' educational experiences. Nurse Education Today, 33(4), 419-424.

5. Evans, W., \& Kelly, B. (2004). Pre-registration diploma student nurse stress and coping measures. Nurse Education Today, 24(6), 473-482.

6. Kang, Y. S., Choi, S. Y., \& Ryu, E. (2009). The effectiveness of a stress coping program based on mindfulness meditation on the stress, anxiety, and depression experienced by nursing students in Korea. Nurse Education Today, 29(5), 538-543.

7. Ergin, E., Çevik, K., \& Pakiş Çetin, S. (2018). Hemşirelik Öğrencilerinin Eğitimlerine İlişkin Algıladığı Stres ve Stresle Baş Etme Davranışlarının İncelenmesi. Hemşirelikte Araştırma ve Dergisi, 15(1), 16-22.

8. Burnard, P., Haji, H. T. B. P. D., Rahim, A., Hayes, D., \& Edwards, D. (2007). A descriptive study of Bruneian student nurses' perceptions of stress. Nurse Education Today, 27(7), 808-818. https://doi.org/10.1016/j.nedt.2006.11.002

9. Liu, M., Chan, Y. M., Tee, S., Gu, K., Luo, Z. M., \& Wong, T. K. S. (2019). An iterative approach to enhance the clinical learning experience in Macao nursing education. International Journal of Nursing Sciences, 6(2), 216-220. https://doi.org/10.1016/j.ijnss.2019.01.005

10. Sritoomma, N., \& Domkrang, N. (2017). Stress levels and coping patterns of nursing students in an international program practicum. The Malaysian Journal of Nursing, 9(2), 64-70.

11. Killam, L. A., \& Heerschap, C. (2013). Challenges to student learning in the clinical setting: A qualitative descriptive study. Nurse Education Today, 33(6), 684-691.12.

12. Jimenez, C., Navia-Osorio, P. M., \& Diaz, C. V. (2010). Stress and health in novice and experienced nursing students. Journal of Advanced Nursing, 66(2), 442-455. https://doi.org/10.1111/j.1365-2648.2009.05183.x

13. Oermann, M. H., \& Lukomski, A. P. (2001). Experiences of students in pediatric nursing clinical courses. Journal for Specialists in Pediatric Nursing, 6(2), 65-72. https://doi.org/10.1111/j.1744-6155.2001.tb00123.x

14. Karaca, A., Yıldırım, N., Ankaralı, H., Açıkgöz, F., \& Akkuş, D. (2014). Hemşirelik Eğitimi Stres Ölçeği'nin Türkçeye uyarlanmas1. Turkish Journal of Research \& Development in Nursing, 16(2), 29-40.

15. Ağaçdiken, S., Mumcu-Boğa, N., \& Özdelikara, A. (2016). Hemşirelik öğrencilerinin hemşirelik eğitimine yönelik yaşadıkları stres düzeyinin belirlenmesi. Samsun Sağlık Bilimleri Dergisi, 1(1), 25-41.

16. Güler, Ö., \& Çınar, S. (2010). Hemşirelik Öğrencilerinin Algıladıkları Stresörler ve Kullandıkları Başetme Yöntemlerinin Belirlenmesi. Maltepe Üniversitesi Hemşirelik Bilim ve Sanatı Dergisi, 253-261.

17. Karagözoğlu, Ş., Özden, D., Türk, G., \& Yıldız, F. T. (2014). Klasik ve entegre müfredat programı hemşirelik öğrencilerinin ilk klinik uygulamada yaşadıkları kaygı, klinik stres düzeyi ve etkileyen bazı faktörler. Dokuz Eylül Üniversitesi Hemşirelik Fakültesi Elektronik Dergisi, 7(4). 
18. Özgan, H., Balkar, B., \& Eskil, M. (2008). Eğitim fakültesi öğrencileri tarafindan sınıfta algılanan stres nedenleri ve kişisel değişkenlerin strese olan etkisi. Elektronik Sosyal Bilimler Dergisi, 7(24), 337-350.

19. Singh, A., Chopra, M., Adiba, S., Mithra, P., Bhardwaj, A., Arya, R., et al.. (2013). A descriptive study of perceived stress among the North Indian nursing undergraduate students. Iranian Journal of Nursing and Midwifery Research, 18(4), 340-342.

20. Taşdelen, S., Zaybak, A. (2013). Hemşirelik öğrencilerinin ilk klinik deneyim sırasındaki stres düzeylerinin incelenmesi. Florence Nightingale Hemşire Derg. 21(2):101-106.

21. Çakmak, Ö., \& Hevedanlı, M. (2005). Eğitim ve Fen-Edebiyat Fakülteleri Biyoloji Bölümü Öğrencilerinin Kaygı Düzeylerinin Çeşitli Değiş̧kenler Açısından İncelenmesi. Elektronik Sosyal Bilimler Dergisi, 4(14), 115-127. 